\title{
Asean Dan Pembangunan Ekonomi Maritim Kepulauan Riau - Indonesia
}

\author{
Akhirman \\ Fakultas Ekonomi Universitas Maritim Raja Ali Haji, Tanjungpinang, Kepulauan Riau, Indonesia
}

\begin{abstract}
Abstrak : Penelitian ini bertujuan untuk mengetahui Pembangunan Ekonomi Maritim Negara-Negara ASEAN dan Kepulauan Riau - Indonesia. ASEAN dalam bahasa Indonesia dikenal dengan Perbara atau Perhimpunan Bangsa-Bangsa Asia Tenggara merupakan suatu organisasi kerjasama bidang ekonomi dan geopolitik. ariabel yang digunakan dalam penelitian ini yaitu Tingkat Pertumbuhan Ekonomi, Ekspor,. Inflasi, dan IPM. Data yang digunakan adalah data time series yaitu dari tahun 2014-2016. Metode analisis yang digunakan penelitian ini adalah analisis deskriptif dan ekonometrika. Data Bank Dunia, tahun 2017 memprediksi ada tiga negara yaitu Kamboja, Laos dan Myanmar diprediksi akan memiliki pertumbuhan ekonomi paling ekspansif setelah India pada tahun 2017-2019 mendatang, bahkan diperkirakan pertumbuhan ekonominya bisa mencapai 7\%. sementara Indonesia Kuartal II 2017 tumbuh 5,1 persen (BPS, 2017), sementara tahun 2013 tumbuh 5,58 persen. Kepulauan Riau, Kota kecil yang menawan bagian dari NKRI pada tahun 2015 pertumbuhan ekonomi 6,02 persen (yoy), pada triwulan II 2017 harus rela dengan pertumbuhan ekonomi nomor dua terbawah tingkat nasional, yaitu 2,02 persen yang sebelumnya merupakan tertinggi se Sumatera, melampaui angka nasional sebesar 4,79 persen. (yoy). Saran yang diberikan dalam penelitian ini antara lain perlu dipikirkan strategi kebijakan yang terhadap pada daerah-daerah yang berpotensi ekonomi guna menunjang pertumbuhan ekspor yang berkalanjutan sehingga mampu meningakatkan pertumbuhan ekonomi yang lebih baik.
\end{abstract}

Kata Kunci : Pertumbuhan Ekonomi, Ekspor, Inflasi, dan IPM

\begin{abstract}
This study aims to find out the Maritime Economic Development of ASEAN Countries and Riau Islands - Indonesia. ASEAN which was established on August 8, 1967 through the Bangkok Declaration by Indonesia, the Philippines, Malaysia, Singapore, and Thailand. Then in 1984 he joined the State of Brunei Darussalam, in 1995 followed by the country of Vietnam, in 1997 the countries of Laos and Myanmar, and in 1998 joined the country of Cambodia. ASEAN in the Indonesian language known as Perbara or Perhimpunan Nations of Southeast Asia is a collaborative organization in the field of economy and geo-politics. The variables used in this study are Economic Growth, Export Rate. Inflation, and IPM. The data used is time series data, namely from 2014-2016. The analytical method used in this study is descriptive and econometric analysis. World Bank data, in 2017, predicts that there are three countries, namely Cambodia, Laos and Myanmar, which are predicted to have the most expansive economic growth after India in 2017-2019, and it is estimated that economic growth can reach 7\%. while Indonesia in Quarter II 2017 grew 5.1 percent (BPS, 2017), while in 2013 it grew 5.58 percent. Riau Islands, a small town that captures part of NKRI in 20156.02 percent (yoy) economic growth, in the second quarter of 2017 must be willing with the lowest number two national economic growth, which is 2.02 percent which was the highest in Sumatra exceed national figures of 4.79 percent. (yoy). Suggestions given in this study include the need to think about a policy strategy that has potential economic areas to support sustainable export growth so that it can improve economic growth better.
\end{abstract}

Keywords: Economic Growth, Exports, Inflation, and IPM

Email Address : 4akhirman@gmail.com 


\section{Pendahuluan}

Pembangunan ekonomi suatu negara pada hakekatnya merupakan suatu rangkaian kegiatan yang dilaksanakan secara sadar, terprogram, dan terus menerus untuk mewujudkan keadaan yang lebih baik secara bersama-sama dan berkesinambungan. Selain menciptakan pertumbuhan ekonomi yang setinggi- tingginya juga bertujuan untuk menghapus atau mengurangi tingkat kemiskinan, ketimpangan pendapatan, dan tingakt pengangguran (Todaro, 2000).

Hal ini sesuai dengan paradigma pembangunan modern yang mengedepankan dethronement of GNP (Penurunan tahta pertumbuhan ekonomi), pengentasan garis kemiskinan, pengurangan distribusi pendapatan yang semakin timpang, dan penurunan tingkat pengangguran yang ada. Sehingga paradigma ini membawa perubahan dalam paradigma bahwa pembangunan harus dilihat sebagai suatu proses yang multidimensional (Kuncoro, 2004).

Pada tahun 2003 kawasan perdagangan bebas ASEAN (AFTA) mulai diberlakukan. Konsekuensinya, barang-barang produksi negara-negara ASEAN telah "bebas" masuk di kawasan tersebut tanpa bisa dihindari karena segala bentuk tariff dan hambatan ekspor-impor dihilangkan atau ditekan serendah mungkin (maksimal $5 \%$ ).

Setelah diberlakukannya AFTA 2003 tersebut, persaingan produk-produk industry dalam negeri harus bersaing menghadapi produk-produk dari luar negara yang relative lebih murah dan berkualias akhirnya dapat merugikan industry dalam negeri. Berdasarkan data Global Comptetitiveness Report (2004), posisi Indonensia dalam Growth Competitiveness Index 2004 (GCI) berada pada urutan 69 , posisi tersebut masih jauh dibawah negara-engara ASEAN lainnya. Seperti Singapura, Malaysia, dan Thailand, poisisi Indonesia hanya bersaing dengan Philipina dan Vietnam. Sedangkan dalam Business Competitiveness Index 2004 (BCI), posisi Indonesia lebih baik dari Philipina dan
Vietnam. Namun tidak dapat mengimbangi Singapura, Malaysia dan Thailand. Walaupun Kawasan Kepulauan Riau merupakan bagian dari Negara Indonesia dikenal sebagai kawasan Industri, Pariwisata dan Perdagangan yang berbatasan langsung dengan Singapura, pada tahun 2014 memberi konstribusi terhadap pertumbuhan ekonomi cukup besar terhadap ekonomi nasional, yaitu 6,6 persen belum mampu untuk menyaingi pertumbuhan ekonomi Singapura.

Sejak tanggal 31 Desember 2015, ASEAN dipersatukan menjadi sebuah komunitas yang bercita-cita untuk menciptakan pasar bebas di kawasan Asia Tenggara guna menarik investasi asing. Masuknya modal asing ke kawasan ini diharapkan dapat menciptakan lapangan kerja baru, mendorong integrasi ekonomi dan meningkatkan kesejahteraan penduduk di kawasan ini. Selain itu Masyarakat Ekonomi Asean (MEA) mendukung pengembangan sumber daya manusia dan pengakuan kualitifikasi profesi khusunsya dalam bidang pekerjaan tertentu seperti dokter, perawat. Berdasarkan uraian di atas, maka penulis melakukan penelitian dengan judul ASEAN dan Perkembangan Ekonomi Maritim Kepulauan Riau Indoensia.

\section{Tinjauan Pustaka}

Pertumbuhan ekonomi adalah kenaikan kapasitas dalam jangka panjang dari negara yang bersangkutan untuk menyediakan berbagai barang ekonomi kepada penduduknya yang ditentukan oleh adanya kemajuan atau penyesuaian teknologi, institusional (kelembagaan), dan ideologis terhadap berbagai tuntutan keadaan yang ada (Kuznetz dalam Todaro, 2004). Pertumbuhan ekonomi berkaitan dengan kenaikan produksi suatu negara atau kenaikan pendapatan per kapita suatu negara. Oleh karena itu pertumbuhan ekonomi erat kaitannya dengan produk domestik bruto (PDB) atau produk domestik 
regional bruto (PDRB) jika dalam lingkup daerah. Beberapa hasil kajian dan penelitian telah diperoleh bahwa pertumbuhan ekonomi, IPM, dan kemiskinan memiliki keterkaitan yang erat. Asian Development Bank (2008) menyatakan bahwa pertumbuhan ekonomi yang dinamis telah banyak mengurangi kemiskinan. Jumlah penduduk yang berjuang untuk hidup dengan $\$ 1$ atau kurang per hari telah turun dari 900 juta tahun 1990 menjadi 600 juta sekarang. Ini dapat diartikan sebagai peningkatan pendidikan, kesehatan yang lebih baik, usia yang lebih panjang, dan kesempatan yang lebih besar.

Siregar dan Wahyuniarti (2008) meneliti mengenai dampak pertumbuhan ekonomi terhadap penurunan jumlah penduduk miskin diperoleh hasil bahwa pertumbuhan ekonomi berpengaruh signifikan terhadap penurunan jumlah penduduk miskin walaupun dengan magnitude yang relatif kecil, seperti inflasi, populasi penduduk, share sektor pertanian, dan sektor industri. Selain itu Sjafi'i dan Hidayati (2009) menyatakan bahwa Tersedianya SDM yang berkualitas ini merupakan syarat penting berlangsungnya pembangunan ekonomi secara berkesinambungan. Pengalaman pembangunan ekonomi negara macan Asia (Korea Selatan, Singapura, Taiwan, Hongkong) membuktikan investasi modal manusia (lewat proses pendidikan) lebih "mujarab" dibanding investasi fisik (gedung, infrastruktur lainnya). Sitepu dan Sinaga (2003) mengkaji mengenai dampak investasi sumber daya manusia terhadap kemiskinan diperoleh hasil bahwa Investasi sumberdaya manusia untuk pendidikan dapat menurunkan poverty incidence, poverty depth dan poverty severity kecuali untuk rumah tangga bukan pertanian golongan atas di desa, bukan angkatan kerja di kota dan bukan pertanian golongan atas di kota, sedangkan investasi kesehatan hanya di rumahtangga bukan pertanian golongan atas di kota yang mengalami peningkatan sementara rumahtangga lainnya mengalami penurunan indeks kemiskinan.

\section{Metode Penelitian}

Penelitian ini mengenai ASEAN dan Pembangunan Ekonomi Maritim Kepulauan Riau - Indoensia. Peneliti melakukan studi empiris dengan obyek penelitian Provinsi Kepualaun Riau, dan negara-negara perbatasan dengan Kepualaun Riau. Untuk variabel Pertumbuhan Ekonomi, Ekspor, Inflasi dan IPM. Adapun data yang digunakan dalam penelitian ini merupakan data sekunder yang diperoleh dari Badan Pusat Statistik (BPS). Variabel-variabel yang diteliti dalam penelitian ini yaitu variabel PDB, EKSPOR, INFLASI, dan IPM, daeri negara-negara tersebut dan Kepulauan Riau. Teknik analisis dalam penelitian ini yaitu analisis regresi data panel, adapun model regresinya dalam bentuk log dapat ditulis sebagai berikut:

$\ln Y$ it $=\beta 0+\beta 1 \ln X 1$ it $+\beta 2 \ln X 2$ it + eit

dimana: $\mathrm{Y}=$ Pembangunan Kemariman Kepulauan Riau

$\mathrm{X} 1=$ Perbumbuhan ekonomi $(\%)$

$\mathrm{X} 2=$ Ekspor

$\mathrm{X} 3=$ Inflasi

$\mathrm{X} 4$ = IPM;

$\mathrm{i}=$ Negara-negara $;$ dan $\mathrm{t}=$ waktu .

Ada dua pendekatan mendasar yang digunakan dalam menganalisis data panel. Pertama, pendekatan Fixed Effect yaitu teknik mengestimasi data panel dengan menggunakan variabel dummy untuk menangkap adanya perbedaan intersep. Kedua, pendekatan Random Effect yaitu estimasi data panel dimana residual mungkin saling berhubungan antar waktu dan antar individu. Sebelum model diestimasi dengan model yang tepat, terlebih dahulu dilakukan uji spesifikasi apakah Fixed 
Effect atau Random Effect atau keduanya memberikan hasil yang sama.

\section{Pembahasan}

1. Pertumbuhan Ekonomi

Pertumbuhan ekonomi Singapura dan Indonesia secara bersamaan mengalami penurunan dari tahun-tahun sebelumnya jika pada tahun 2014

Indonesia pada pertumbuhan ekonomi 5,1 persen pada tahun 2016 hanya mampu tumbuh pada angka 5,2 persen padahal tahun 2013 tumbuhn pada angka 5,78 pesen. Anjloknya pertumbuhan ekonomi Singapura disebabkan anjloknya pasar industry jasa, penurunan kucuran kredit per-bankan, turunnya pasar elektronik Singapura ke China. Perkembangan pertumbuhan ekonomi di negara-negara ASEAN dan Kepri dapat dilihat dari grafik berikut.

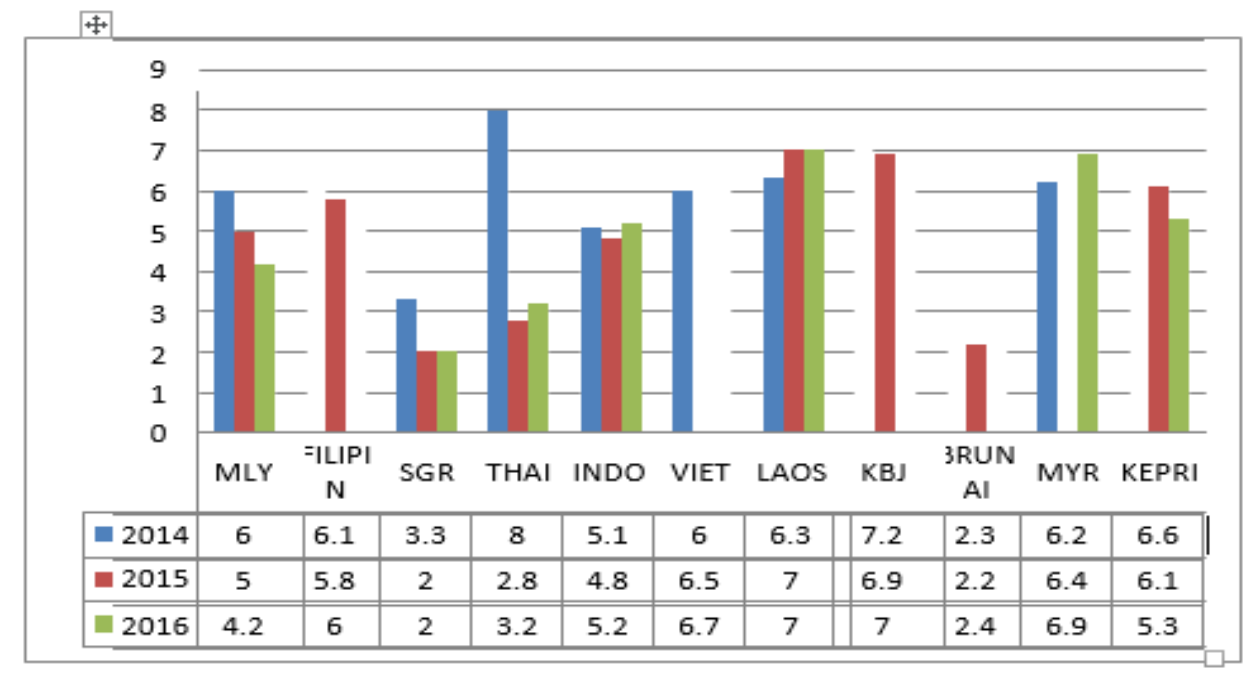

Grafik 1. Pertumbuhan ekonomi negara-negara ASEAN

Sumber : BPS. Pusat (data diolah 2014,2017)

Sejalan dengan merosotnya pertumbuhan ekonomi ASEN berpengaruh terhadap pertumbuhah ekonomi Provinsi Kepulauan Riau. Dari pertumbuhan pada tahun 2014 sebesar 6,6 pesern, tertinggi di sumatera, pada Triwulan II tahun 2017 turun drastis hingga pada angka 2,02 persen. Ini pertumbuhan ekonomi kurang baik di Kepulauan Riau, hingga berada pada posisi ke dua terahir tingkat nasional. Dengan demikian secara langsung berdampak terhadap pertumbuhan ekonomi nasional.

\section{Ekspor}

Ekspor negara-negara ASEAN sangat memiliki ketergantungan dan mempengaruhi satu sama lainnya. Dan saling tarik menarik yang tidak dapat dipungkiri, Jika sebelum tahun 2014 Indonesia adalah negara yang memiliki pertumbuhan ekspor yang cukup baik, seperti dialami oleh Kepulauan Riau dari Kawasan Industri pulau Batam. Akhir-akhir ini ekspor tersebut turun hingga mencapai dibawah miliyar rupiah. Alasan penutupan hingga puluhan perusahaan di Pulau Batam adalah salah satu faktor turunnya ekspor tersebut. Penutupan industry di Batam meningkatkan pertumbuhan ekonomi negara seperti Philipina, Laos dan Kamboja. Mungkin persabahatan tidak selalu mendukung, karena faktor kepentingan politik dan ekonomi internal negara masing-masing terhadap negara tujuan ekspor negara bersangkutan. Bagaimana kondisi ekspor negara-negara ASEAN dapat diketahui dari grafik berikut ini. 


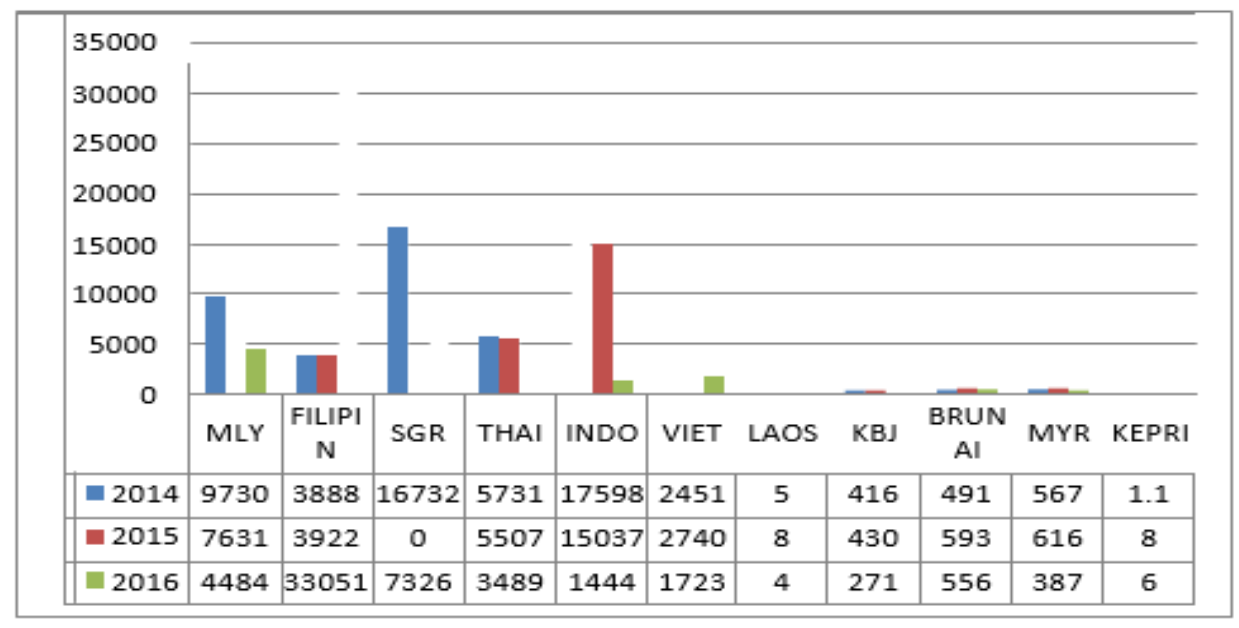

Grafik 2. Perkembangan ekspor negara-negara ASEAN

Sumber : BPS Pusat, (data diolah 2014-2017)

Dari grafik di atas dapat diketahui, bahwa ekspor Singapura dan Indoensia berdampingan pada angka yang tidak jauh seperti pada tahun 2014 ekspor Singapura US\$ 16,732 milyar, dan Indoensia US\$ 17.598 milyar. Namun kemudian ekonomi Singapura terpuruk maka Indoensia juga ikut menanggung dampaknya. Pada Triwulan II tahun 2017 realisasi ekspor Indonesia turun drastis pada angka US\$ 1.444 miliyar. Sementara pada tahun 2014 ekspornya mencapai US\$ 17.598 miliyar. Hal ini juga berdampak terhadap ekspor Kepulauan Riau sebagai wilayah mitra ekspor Singapura, jumlah ekspor Kepri dari tahun 2014 US\$ 1.1 juta, pada tahun 2015 dan 2016 turun menjadi US\$ 8 dan 6 juta.

Terhadap nilai ekspor. Ekspor Provinsi Kepulauan Riau berdasarkan data BPS, Kepri (2017) selama tiga tahun terahir per-bulannya tumbuh dengan fluktuatif, jika pada bulan Janauri tahun 2014 berjumlah 1.528456944 juta dolar AS, ditutup pada bulan Desember tahun yang sama sebesar 1.180365265 (mengalami penurunan),

Ekspor pada Janauri tahun 2015 berjumlah 1005015757 juta dollar AS, dan pada Desember tahun 2015 berjumlah 846 685883 juta dollar AS, selanjutnya Ekspor pada bulan Januari 2016 berjumlah 688574 998 juta dollar AS, dan ditutup pada Desember 2016 berjumlah 882222110 juta dollar AS. Penurunan ekspor ini adalah dampak dari lebih 60 perusahaan yang tutup (tidak beroperasi) selama dua tahun terahir ini yang diakibatkan oleh ketidakpastian Hukum terhadap tarik ulur pengelolaan Kawasan Batam oleh pemerintah dan BP. Kawasan Batam.

3. Inflasi

Dari pengertiannya inflasi adalah suatu keadaan dimana harga barang secara umum mengalami kenaikan secara terus menerus berkaitan dengan mekanisme pasar yang dapat disebabkan oleh berbagai faktor, antara lain konsumsi masyarakat yang meningkat, berlebihnya likuiditas di pasar yang memicu konsumsi atau bahkan spekulasi, sampai termasuk juga akibat adanya ketidaklancaran distribusi barang.

Unuk mengetahui inflasi negara-negara ASEAN seperti berikut ini. 


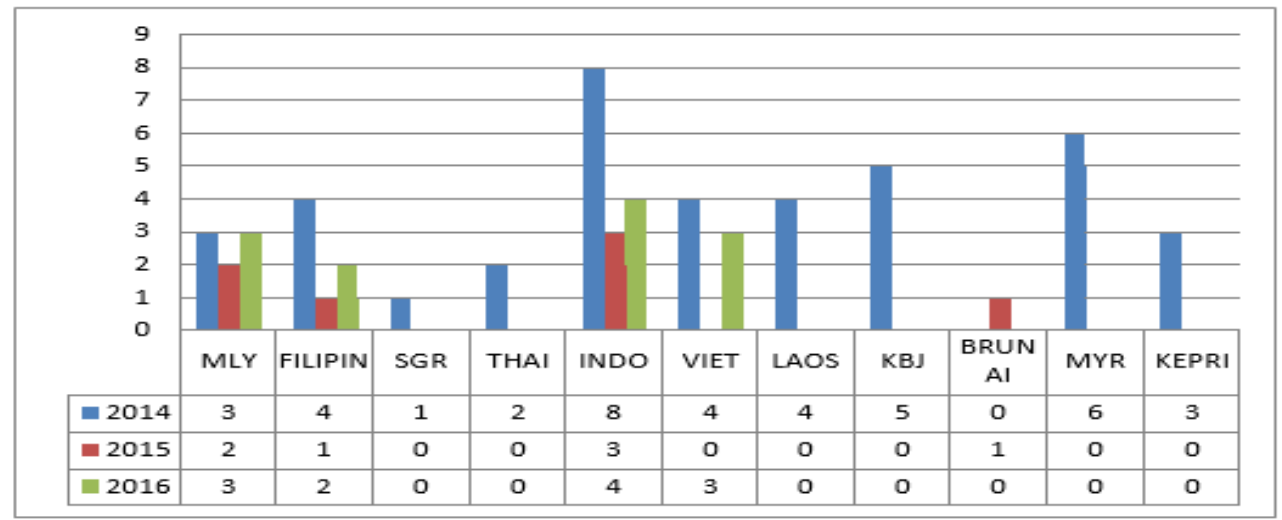

Grafik 3. Perkembangan inflasi negara-negara ASEAN Sumber : BPS Pusat, 201-2017 (Data diolah)

Dari grafik di atas, diketahui bahwa pada tahun 2014 inflasi Indoensia tertinggi di ASEAN hingga mencapai 8 persen. dan terendah adalah Singapura, Untuk Brunei Darussalam data inflasi dan lainnya tidak cukup lengkap. Hingga tahun 2016 inflasi Indoensia masih tertinggi hinga 4 persen. Sementara Singapura $(-0.5$ dan $-0,6)$ persen, inflasi Kepri tahun 2014 sebesar 3 persen, tahun

2015 dan 2016 turun pada angka 0,9 persen dan 0,4 persen.

\section{IPM}

Indeks Pembangunan Manusia (IPM) adalah salah satu indikator bagaimana negara membangun masyarakatnya sehingga mencapai tujuan dasar yang menjadi sasaran suatu pembangunan negara tersebut. Data IPM untuk negara- negara ASEAN, diperoleh data tahun 2014 dan 2015. Berdasarkan data dari Human Development Report (HDR), dengan data terakhir tahun 2014, Indonesia masih menempati urutan ke lima (5), di bawah Singapura, Brunei, Malaysia dan Thailand, dengan 0,738.poin, sedangkan SIngapura yang menempati posisi teratas yaitu 0,924 poin sekaligus menempai ranking 11 dunia, sementara IPM Provinsi Kepri adalah 0,734 tahun 2014 dan 0,735 tahun 2015. Untuk mengetahui data perkembangan IPM negaranegara ASEAN dapat diketahui dari grafik berikut ini.

Tabel 1. Data perkembangan IPM Negara-Negara ASEAN

\begin{tabular}{|l|c|c|}
\hline \multirow{2}{*}{ NEGARA } & \multicolumn{2}{c|}{ Tahun } \\
\cline { 2 - 3 } & 2014 & 2015 \\
\hline Malaysia & 0,789 & 0,789 \\
\hline Filipina & 0,668 & 0,682 \\
\hline Singapura & 0,924 & 0,925 \\
\hline Thailand & 0,738 & 0,740 \\
\hline Indonesia & 0,686 & 0,689 \\
\hline Vietnam & 0,678 & 0,683 \\
\hline Laos & 0,582 & 0,586 \\
\hline Kamboja & 0,558 & 0,563 \\
\hline Brunei Darussalam & 0,863 & 0,865 \\
\hline Myanmar & 0,552 & 0,556 \\
\hline Kepri & 0,734 & 0,735 \\
\hline
\end{tabular}

Sumber : http://hdr.undip.org/en/countries 
Singapura adalah negara dengan angka harapan hidup tertinggi yaitu 83 tahun, disusul dengan Brunei 78,8 tahun. Angka harapan hidup Indonesia yaitu 68,9 tahun. Artinya penduduk Indonesia rata-rata hidup selama 68,9 tahun. Paling rendah yaitu Myanmar, dengan angka 65,9 tahun. Hasil ini sama dengan peringkat IPM Myanmar di ASEAN yang paling rendah.

IPM Indonesia agak tertolong dengan program fasilitas yang diberikan oleh pemerintah Indonesia melalui program Presiden Joko Widodo, yaitu melalui KJS, KIS, KIP, seperti Provinsi Kepri berasarkan data BPS Model Baru bahwa IPM tidak berpengaruh langsung terhadap Pertumbuhan ekonomi.

\section{Perbandingan ASEAN dan Kepulauan Riau-Indoensia}

Tidak logis membandingkan Kepulauan Riau dengan negara-negara ASEAN, namun pada kenyataannya aktivitas masyarakat, transaksi keuangan, serta faktor pendorong dan mundurnya perekonomian di Kepulauan Riau, ASEAN memberi kontribusi yang sangat kuat dan nyata. Pada saat ini tanpa diduga, dan direncanakan bahwa Batam sebagai pusat pertumbuhan ekonomi dari sektor industry, perdagangan saat ini tidak menjadi primadona lagi. Beberapa kesenjangan antar negara dan wilayah kerjasama perbatasan mulai terlihat, diataranya.

Berdasarkan hasil-hasil studi kuantitatif yang telah dilakukan pada tahun 1990-an, misalnya Levine dan Renelt (1992) menemukan bukti adanya korelasi positif dan signifikan antara investasi dengan pertumbuhan ekonomi. Disamping itu studistudi lain yang memakai analisis fungsi produksi neo-klasik menemukan bahwa investasi, bukan progres teknologi, merupakan faktor utama dibalik pertumbuhan ekonomi yang cemerlang yang dialami negara-negara Asia Tenggara. Argumen utama dibalik hasil dari studi-studi ini adalah bahwa investasi menambah jumlah stok kapital per pekerja dan oleh karena itu menaikkan produktivitas.

6. Penelitian Sebelumnya

Sinha (1999) menemukan adanya hubungan yang negatif antara ketidakstabilan ekspor dengan pertumbuhan ekonomi di negara Jepang, Malaysia, Philipina, dan Sri Langka. Sementara itu, untuk negara Korea, Myanmar, Pakistan, dan Thailand menunjukkan pengaruh yang positif antara ekspor dan pertumbuhan ekonomi. Sedangkan pada sisi yang lain, ditemukan juga dampak yang positif antara pertumbuhan ekonomi dan investasi domestik.

Kweka dan Morrissey (2000), menunjukkan bahwa meningkatnya pengeluaran produktif (investasi fisik) ternyata memberikan pengaruh yang negatif terhadap pertumbuhan ekonomi di Tanzania. Sementara pengeluaran untuk konsumsi terutama konsumsi swasta berhubungan positif dan signifikan dengan pertumbuhan ekonomi. Sedangkan pengeluaran publik untuk human capital tidak signifikan secara statistik terhadap pertumbuhan ekonomi di Tanzania. Disamping itu dari hasil estimasi memperlihatkan bahwa pengeluaran investasi publik di Tanzania tidak produktif dan ini berlawanan dengan pendapat yang lebih luas, dimana pengeluaran konsumsi pemerintah Tanzania telah menurunkan pertumbuhan ekonomi.

Wong dan Jomo (2001) yang menganalisis dampak arus modal asing terhadap pertumbuhan ekonomi di Malaysia menemukan bahwa investasi dan pertumbuhan sektor manufaktur berpengaruh positif dan signifikan, sedangkan pertumbuhan angkatan kerja memberikan pengaruh positif tetapi tidak signifikan terhadap pertumbuhan ekonomi di Malaysia selama kurun waktu 1966 - 1996.

Darrat, dkk (2005), hasil empirisnya menunjukkan bahwa arus FDI berpengaruh positif dan menjadi faktor stimulus bagi pertumbuhan ekonomi di negara-negara Eropa (CEE). Sedangkan dampak FDI terhadap pertumbuhan ekonomi di negara-negara Timur 
Tengah dan Afrika Utara (MENA) tidak konsisten atau berpengaruh negatif. Sementara untuk angkatan kerja, ekspor, utang luar negeri, dan inflasi berpengaruh negatif terhadap pertumbuhan ekonomi baik di Eropa dan MENA, namun untuk pengeluaran pemerintah berpengaruh positif di kedua wilayah penelitian tersebut.

\section{Analisis Hasil Estimasi}

\subsection{Pertumbuhan Ekonomi ASEAN}

Semenjak tahun 2003, ASEAN merupakan kawasan yang bebas untuk anggotanya melakukan perdagangan bebas antar negara ASEAN. Hal ini semestinya dapat mengambil peluang dan tantangan bagi setiap negara ASEAN untuk memacu pertumbuhan ekonominya terhadap kepentingan negara-negara maju lainnya.

Berdasarkan data yang ditampilkan di atas rata-rata pertumbuhan ekonomi ASEAN pada tahun 2014 adalah 5,65 persen. Pada tahun 2015 turun pada angka 4,94 persen. Dan pada tahun 2016 tumbuh dengan angka 5,06 persen. Sementara rata- rata tiga tahun tersebut adalah 5,22 persen.

\subsection{Perkembangan Ekspor ASEAN}

Berdasarkan data di atas, maka aktivitas Ekspor negara ASEAN pertahun 2014 adalah rata-rata US\$ 5.245,1 miliyar, tahun 2015 rata-rata berjumlah US\$ 4.911,9 miliyar, dan pada tahun 2016 rata-rata berjumlah US\$ 2.298,7 miliyar. Artinya selamata tiga tahun berturut-turut aktivitas ekspor sepuluh negara ASEAN terus mengalami penurunan yang cukup signifikan.

\subsection{Perkembangan Inflasi negara ASEAN}

Dari data di atas, diketahui bahwa tingkat inflasi negara-negara ASEAN cukup stabil cenderung turun, pada tahun 2014 rata-rata inflasi negara ASEAN tersebut adalah 3,7 persen, rata- rata inflasi tahun 2015 adalah 0,7 persen. Berdasarkan teori bahwa inflasi mencapai titik angka (0) mengindikasikan ekonomi mengalami kekakuan atau menunggu pada hargaharga tertentu praktis tak berubah (inflasi $0 \%$ ). Kemudian rata-rata inflasi pada tahun 2016 adalah 1,2 persen. Untuk rata- rata selama tiga tahun tersebut a dalah 1,86 persen.

\subsection{Perkembangan IPM}

Adapun perkembangan IPM negaranegara ASEAN selama tahun 2014 ratarata tumbuh pada angka 0,704 dan pada tahun 2015 rata-rata tumbuh dengan angka 0,708 poin. Sementara untuk untuk rata-rata selama tiga tahun tersebut adalah 0,706 poin.

\section{Kesimpulan}

Adapun kesimpulan dari penelitian ini adalah :

1. Provinsi Kepulauan Riau khususnya Batam, sangat dipengaruhi oleh aktivitas ekonomi negara-negara ASEAN terutama adalah Negara Singapura sebagai negara tujuan ekspor dari wilayah Kepri, berdasarkan data BPS (2010) eskpor dari Kepulauan Riau ke Singapura mencapai 711,17 juta dolar AS atau 67,08 persen dari total pada saat itu.

2. Provinsi Kepulauan Riau sangat dipegnaruhi oleh kurs mata uang dolar Singapura, terhadap harga-harga barang dan jasa yang di pasarkan di wilayah Kepulauan Riau, khususnya Batam, Karimun, Bintan, dan Tanjungpinang.

3. Pertumbuhan ekonomi dan perkembangan industry di Kepualaun Riau akan mengalami penurunan pasa industry (investor) asing bilamana pemerintah pusat dan pemerintah daerah Kepualaun 
Riau tidak berkoordinasi dalam pengelolaan kawasan-kawasan industry dan perdangan khususnya pada kawasan bebas dan pelabuhan bebas yang ditetapkan oleh pemerintah. Industri akhir-akhir ini telah memasuki negara seperti Laos, Kamboja, dan Myanmar seperti yang dilansir oleh Bank Dunia,

4. Provinsi Kepulauan Riau akan mengalami dampak sosial yang sangat berarti yaitu meningaktkan angka pengangguran, akibat banyaknya perusahaan yang menutup akvitas operasional perusahaannya di wilayah Kepri, khususnya Batam dikarenakan kebutuhan koordiansi antar dua instansi yaitu pemeritnah dan BP. Kawasan sebagai pengelola kawasan bebas dan pelabuhan bebas.

\section{Saran}

1. Untuk meningkatkan pertumbuhan ekonomi di masing-masing negara ASEAN,khususnya Indonesia, maka kontribusi investasi harus ditingkatkan terutama terhadap teknologi, Infrastruktur pengembangan pembangaunan Ekonomi Maritim sebagai poros dunia yang dicitacitakan.

2. Pengembangan SDM harus segera terus menjadi prioritas menghadapi persaingan negara-negara ASEAN lainnya seperti Laos, Kamboja dan Myanmar, yang saat ini terus mengejar ketertinggalan mereka.

3. Untuk mendorong laju pertumbuhan ekonomi pemerintah Indoensia harus mendorong masyarakatnya untuk lebih kreatif membuka diri, dan pengambil peluang dari glolabisasi industry, perdagangan dan Pariwisata.

4. Untuk mempercepat pemulihan ekonomi di Kepulauan Riau, pemerintah Pusat, Provinsi, Kota/Kabupaten dan BP. Kawasan harus sesegera melakukan harmonisasi, koordinasi dalam pengelolaan kawasan dan memberikan kepastian Hukum bagi investor.

\section{Daftar Pustaka}

Asean Development Bank (2008).

Bank Dunia (2017), Asian Development Bank. 2005. Asian Development Outlook

BPS Provinsi Kepulauan Riau, (2014-2017)

BPS Pusat (2014-2017)

BPS Pusat, Laporan Perekonomian Indonesia, (2016)

Budiona, 1955, Teori Pertumbuhan Ekonomi, Yogyakarta, BPFE UGM.

Dumairy. 1997. Perekonomian Indonesia. Jakarta : Penerbit Erlangga

Hidayat, Paidi. 2004. Analisis Pengaruh Arus Modal Asing Terhadap Pertumbuhan Ekonomi di Negara-Negara Islam. Tesis Tidak Dipublikasikan. Medan : Program Studi Magister Ekonomi Pembangunan Pascasarjana USU.

Kuznest, Simon, 1955, "Economic Grouwth and Income Inequality", American Economic Review," Maret.

Sagir, Suharsono. 1989. Membangun Manusia Karya, Masalah Ketenagakerjaan dan Pengembangan Sumber Daya Manusia. Jakarta : Pustaka Sinar Harapan.

Sarjadi, Soegeng dan Sukardi Rinakit. 2004. Meneropong Indonesia 2020, Pemikiran dan Masalah Kebijakan. Jakarta : Soegeng Sarjadi Syndicated (SSS).

Sentsho, Joel. 2000. Export Revenues as Determinants of Economic Growth : Evidence from Botswana. Gaborone 
Department of Economics,
University of Botswana.

Siddique, M dan E.A Selvanathan. 1998.

Export Performance and Economic Growth : Cointegration and Causality Analysis for Malaysia, 1966 - 1996. Australia : University of Western Australia, Department of Economics.

Sinha, Dipendra. 1999. Export Instability, Investment and Economic Growth in Asian Countries : A Time Series Analysis. Economic Growth Center Yale University.

Sjahrir. 1986. Ekonomi Politik Kebutuhan Pokok : Sebuah Tinjauan Prospektif. Jakarta : LP3ES.

Tambunan, Tulus. 2000. Perdagangan Internasional dan Neraca Pembayaran : Teori dan Temuan Empiris. Jakarta : Pustaka LP3ES.

2001. Transformasi Ekonomi di Indonesia : Teori dan Penemuan Empiris. Jakarta : Penerbit Salemba Empat. 